\title{
G-CSF inhibits LFA-1-mediated CD4+ $T$ cell functions by inhibiting Lck and ZAP-70
}

\author{
Shasha Zhao ${ }^{1,2}$, Zhenyang Gu${ }^{1}$, Li Wang ${ }^{1,3}$, Lixun Guan ${ }^{1}$, Feiyan Wang ${ }^{1}$, Nan Yang ${ }^{1}$, \\ Lan Luo ${ }^{1}$, Zhe Gao ${ }^{1}$, Yingwei Song ${ }^{4}$, Lili Wang ${ }^{1}$, Daihong Liu ${ }^{1}$ and Chunji Gao ${ }^{1}$ \\ ${ }^{1}$ Department of Hematology, Chinese PLA General Hospital, Beijing 100853, China \\ ${ }^{2}$ Medical School, Nankai University, Tianjin 300071, China \\ ${ }^{3}$ Department of Hematology and Oncology, Laoshan Branch, No. 401 Hospital of Chinese PLA, Qingdao 266101, China \\ ${ }^{4}$ Department of Blood Transfusion, Chinese PLA General Hospital, Beijing 100853, China \\ Correspondence to: Chunji Gao, email: gaochunji@medmail.com.cn \\ Keywords: granulocyte colony-stimulating factor, CD4+ T cells, lymphocyte function-associated antigen-1, Lck, ZAP-70 \\ Received: July 26, $2016 \quad$ Accepted: May 06, $2017 \quad$ Published: May 25, 2017 \\ Copyright: Zhao et al. This is an open-access article distributed under the terms of the Creative Commons Attribution License \\ 3.0 (CC BY 3.0), which permits unrestricted use, distribution, and reproduction in any medium, provided the original author and \\ source are credited.
}

\section{ABSTRACT}

In this study, we showed that G-CSF mobilization increased the frequency of $\mathrm{T}$ cells, specifically $\mathrm{CD}^{+} \mathrm{CD4}^{+} \mathrm{T}$ cells. G-CSF mobilization decreased the secretion of inflammatory cytokines of CD4 ${ }^{+} T$ cells through the LFA-1/ICAM-1 signaling pathway, whereas it did not alter the TH1/TH2 ratio. We found that G-CSF mobilization inhibited LFA-1-mediated CD4 ${ }^{+} \mathrm{T}$ cell polarization and motility. In vitro, G-CSF stimulation also attenuated the polarization and adhesiveness of $\mathrm{CD4}^{+} \mathrm{T}$ cells through the LFA-1/ ICAM-1 interaction. Further investigation revealed that G-CSF mobilization suppressed LFA-1 signaling by down-regulating Lck and ZAP-70 expression in CD4 ${ }^{+} \mathrm{T}$ cells, similar results was also confirmed by in-vitro studies. These findings suggested that G-CSF directly suppressed LFA-1-mediated $\mathrm{CD4}^{+} \mathrm{T}$ cell functions through the down-regulation of Lck and ZAP-70. The immunosuppressive effect of G-CSF mobilization deepened our understanding about peripheral blood hematopoietic stem cell transplantation. LFA-1/ICMA-1 pathway may become a potential target for graft-versus-host disease prophylaxis.

\section{INTRODUCTION}

Granulocyte colony-stimulating factor (G-CSF), which can mobilize hematopoietic stem cells (HSCs) from the bone marrow to the peripheral blood, is widely used in the field of transplantation. G-CSF is a multiple-functional glycoprotein which plays an important role in regulating adaptive immune responses [1, 2]. G-CSF has both direct and indirect effects on immune cells, including monocytes, granulocytes, T cells and dendritic cells. Moreover, G-CSF alters the expression of cytokines, metalloproteinases and adhesion molecules. These various soluble factors may contribute to the effects on immune cells induced by G-CSF [3-5].

Graft-versus-host disease (GVHD), induced by alloreactive $\mathrm{T}$ cells, is a major complication of allogeneic hematopoietic stem cell transplantation (allo-HSCT) [6, 7]. Thus, suppressing the function of alloreactive $T$ cells has been a major strategy to reduce GVHD $[8,9]$. Based on their cytokine expression pattern, $\mathrm{CD}^{+} \mathrm{T}$ cells can be divided into TH1 and Th2 cells. TH1 cells can secrete interleukin (IL)-2, tumor necrosis factor (TNF)- $\alpha$ and interferon (IFN)- $\gamma$ and play a major pro-inflammatory role in cellular immunity against intracellular pathogens, whereas $\mathrm{TH} 2$ cells, characterized by the production of IL-4, IL-5 and IL-10, paly a predominant role in humoral immunity against extracellular parasites [10]. The ratio of TH1/TH2 cells varied with different pathophysiological conditions, involving in the progression of or protection against some infectious and autoimmune conditions $[11,12]$. 
Lymphocyte function-associated antigen-1 (LFA1) is an integrin expressed on T cells, B cells, NK cells, and neutrophils [13]. Activated LFA-1 interacts with its ligand, intracellular adhesive molecules 1 (ICAM-1), which is inducibly expressed on high endothelial venules and other types of cells during inflammation. The LFA1/ICAM-1 interaction plays a key important role in the adhesion, locomotion and migration of $\mathrm{T}$ cells $[14,15]$, thus increasing the avidity of the T cell/APC interaction at the level of the immunological synapse [16]. Therefore, it is crucial for the activation of T cells [17]. Additionally, LFA-1/ICMA-1 signaling pathway also participates in many intracellular activities, like the remodeling of cytoskeletal systems and activities of many proteins such as signaling proteins, adaptor proteins, enzymes, and transcription factors [18-22].

We have previously found that G-CSF mobilization can inhibit the proliferation and activation of $\mathrm{CD}^{+} \mathrm{T}$ cells through the conformation of LFA-1 [23]. These findings prompted us to consider the possibility of a crucial crosstalk between G-CSF and LFA-1 signaling in the function of $\mathrm{CD}^{+} \mathrm{T}$ cells. In this study, we found that G-CSF decreased the expression of Lck and ZAP-70 in the LFA1 signaling pathway, which ultimately inhibited $\mathrm{CD}^{+} \mathrm{T}$ cell functions.

\section{RESULTS}

\section{G-CSF mobilization increased the frequency of $T$ cells, specifically $\mathrm{CD3}^{+} \mathrm{CD4}^{+} \mathrm{T}$ cells}

Clinical results have shown that the incidence and severity of acute GVHD is comparable between peripheral blood stem cell (PBSC) transplantation and bone marrow transplantation (BMT) [24-26], even though PBSC grafts contain approximately 10 -fold more $\mathrm{T}$ cells than conventional BM grafts [27-29]. A possible reason is that G-CSF, which is used for mobilizing PBSC, alters the functional activities of donor T cells. In this study, we first analyzed the effects of G-CSF mobilization on lymphocyte and $\mathrm{T}$ cell subsets. Peripheral blood mononuclear cells (PBMCs) were obtained from healthy volunteers (control group) and G-CSF mobilized HSC donors (G-CSF mobilization group) with informed consent. Then, PBMCs were stained with corresponding fluorescents labeled antibodies and analyzed by flow cytometry. G-CSF mobilization dramatically increased the frequency of T cells $(67.63 \%$ vs. $59.54 \%, P=0.021)$ but not B cells and NK cells (Figure 1A and 1B). T cell subsets analysis showed that the percentage of $\mathrm{CD}^{+} \mathrm{CD}^{+} \mathrm{T}$ cells was significantly higher in G-CSF mobilized group than in the control group (38.51\% vs. $26.41 \%, P=0.003)$. However, the frequency of $\mathrm{CD}^{+} \mathrm{CD}^{+} \mathrm{T}$ cells was not affected (23.74 \% vs. 23.62\%, $P=0.946$ ) (Figure $1 \mathrm{C}$ and 1D). These data suggested that G-CSF mobilization increased the frequency of $\mathrm{T}$ cells, specifically $\mathrm{CD}^{+} \mathrm{CD}^{+} \mathrm{T}$ cells.
This finding prompted us to further investigate whether and how G-CSF mobilization influences the functions of $\mathrm{CD}^{+} \mathrm{T}$ cells.

\section{G-CSF mobilization inhibited the release of inflammatory cytokines from $\mathrm{CD4}^{+} \mathrm{T}$ cells through the LFA-1/ICAM-1 interaction}

We previously observed that G-CSF decreased $\mathrm{CD}^{+} \mathrm{T}$ cell activation and proliferation by changing the conformation of LFA-1 [23]. Verma and colleagues demonstrated that LFA-1/ICAM-1 ligation could induce the polarization of $\mathrm{T}$ cells to TH1 cells [30]. We then investigated whether G-CSF mobilization influences $\mathrm{CD}^{+} \mathrm{T}$ cells through ICAM-1/LFA-1 interaction. CD4 ${ }^{+}$ $\mathrm{T}$ cells were isolated from healthy volunteers (control group) and G-CSF mobilized HSC donors (G-CSFmobilization group). The purity of the $\mathrm{CD}^{+} \mathrm{T}$ cells was greater than $96 \%$ in the two groups (Figure 2A). There was no difference in the purity of $\mathrm{CD}^{+} \mathrm{T}$ cells between the control group and the G-CSF-mobilization group (Figure 2B). The culture supernatants were collected after stimulation of purified $\mathrm{CD}^{+} \mathrm{T}$ cells in different conditions for $72 \mathrm{~h}$, and the levels of the cytokines, including IL-2, IL-4, IL-10, IFN- $\gamma$ and TNF- $\alpha$, were detected. The results showed that incubation of $\mathrm{CD}^{+} \mathrm{T}$ cells with either ICAM1 or anti-CD3 increased the IL-2 level (Figure 2C). This increase in IL-2 secretion was also observedwhen the cells were stimulated withboth ICAM-1 and anti-CD3. The increase of IL-2 was abrogated when anti-LFA-1 blocking antibody was used (Figure 2C). Compared with the control group, G-CSF mobilization inhibited IL-2 production by $>50 \%$ when the cells were stimulated with both ICAM-1 and anti-CD3 (Figure 2C). Furthermore, LFA-1/ICAM-1 signaling in $\mathrm{CD}^{+} \mathrm{T}$ cells increased the anti-CD3-mediated production of IFN- $\gamma$ and TNF- $\alpha$, which was abrogated in thepresence of anti-LFA-1 blocking antibody (Figure 2D and 2E). G-CSF mobilization also significantly inhibited the release of IFN- $\gamma$ and TNF- $\alpha$ when the cells were stimulated with both ICAM-1 and anti-CD3 (Figure $2 \mathrm{D}$ and $2 \mathrm{E}$ ). In contrast, LFA-1/ICAM-1 stimulation in $\mathrm{CD}^{+} \mathrm{T}$ cells significantly decreased anti-CD3-mediated secretion of IL-4 (Figure 2F) and IL-10 (Figure 2G). In addition, the ICAM-1- and anti-CD3-stimulated secretion of IL-4 and IL-10 in the control group showed 2-fold than the G-CSF-mobilization group (Figure $2 \mathrm{~F}$ and $2 \mathrm{G}$ ). We further analyzed the cellular expression of TH1/TH2 cytokines in LFA-1/ICAM-1- and anti-CD3-stimulated $\mathrm{CD}^{+} \mathrm{T}$ cells using flow cytometry (Figure $2 \mathrm{H}$ ). $\mathrm{CD}^{+}$ $\mathrm{T}$ cells from the G-CSF-mobilization group exhibited significant different in cytokine expression. In comparison to the control group, G-CSF mobilization decreased IFN- $\gamma$ and IL-4 production by more than 50\% (Figure 2I), indicating that G-CSF mobilization suppressed the percentage of $\mathrm{TH} 1$ and $\mathrm{TH} 2$ cells. However, there was no statistically significant difference in the $\mathrm{TH} 1 / \mathrm{TH} 2$ ratio 
between the G-CSF mobilization group and the control group (data not shown). Collectively, these data supported the critical involvement of LFA-1 signaling in $\mathrm{CD}^{+}{ }^{+} \mathrm{T}$ cell cytokine secretion and suggested that G-CSF mobilization decreased the release of inflammatory cytokines from $\mathrm{CD}^{+} \mathrm{T}$ cells through the LFA-1/ICAM-1 interaction but did not alter the balance of the TH1/TH2 subsets.

\section{G-CSF mobilization decreased the polarization and migration of $\mathrm{CD4}^{+} \mathrm{T}$ cells}

Given the crucial role of LFA-1/ICAM-1 in T cell attachment, polarization and migration, we examined whether G-CSF mobilization could affect LFA-1-mediated $\mathrm{CD}^{+} \mathrm{T}$ cell polarization and migration. Purified $\mathrm{CD}^{+} \mathrm{T}$ cells were stimulated in 96-well plates coated with antiCD3 and ICAM-1 and then visualized by fluorescence microscopy after 60 minutes of stimulation. Polarization morphology was detected in the control group and the G-CSF mobilization group (Figure 3A). However, the percentage of polarized cells was significantly lower in the mobilized group than in the control group $(32.37 \%$ vs. $56.32 \%, P<0.0001$ ) (Figure 3B). Moreover, the motility and velocity of the mobilized $\mathrm{CD}^{+} \mathrm{T}$ cells were significantly lower than that of the control group (average speed of 6.82 vs. $9.39 \mu \mathrm{m} / \mathrm{min}, P<0.0001$ ) (Figure $3 \mathrm{C}$ and 3D). Taken together, these results showed that G-CSF mobilization can decrease the polarization and migration of $\mathrm{CD}^{+} \mathrm{T}$ cells.

\section{G-CSF stimulation attenuated the polarization and adhesiveness of $\mathrm{CD}^{+} \mathrm{T}$ cells in vitro}

G-CSF directly affects lymphocytes functions through the G-CSFR [31, 32]. We first analyzed the G-CSFR levels on $\mathrm{CD}^{+} \mathrm{T}$ cells. Purified $\mathrm{CD} 4^{+} \mathrm{T}$ cells were
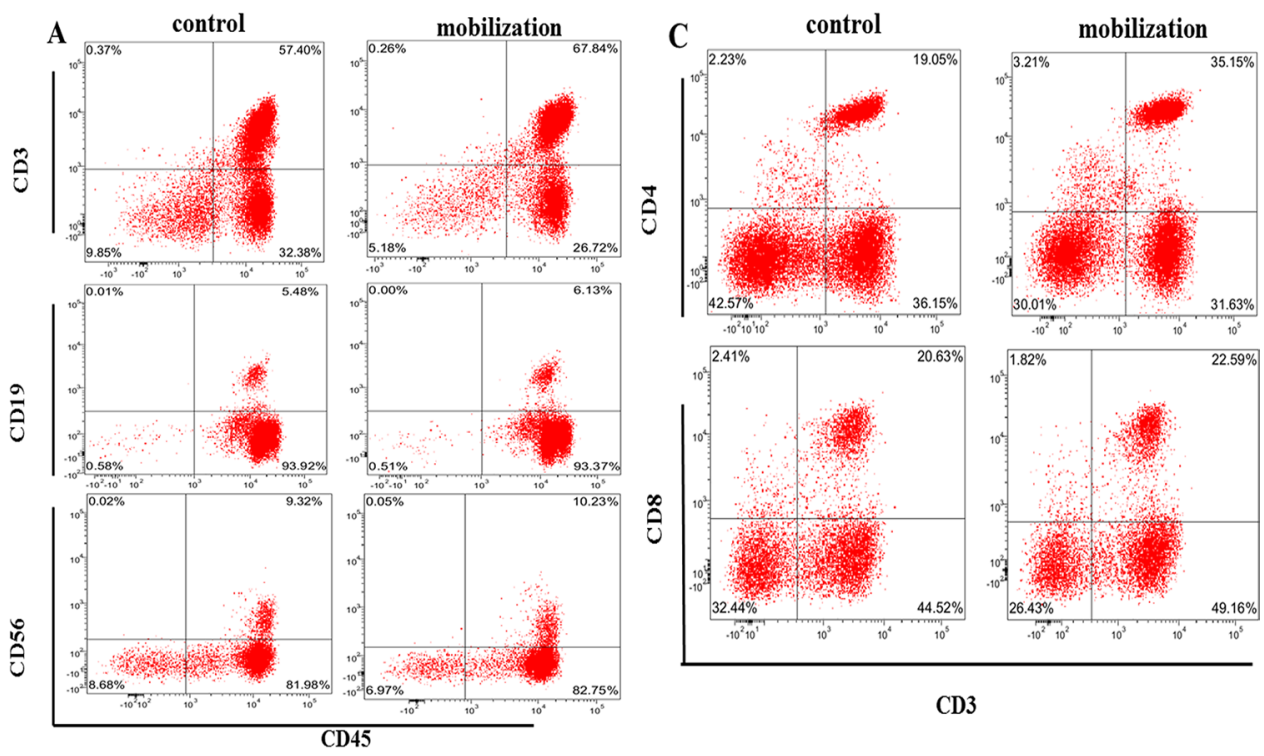

$\mathrm{CD} 3$

B

D
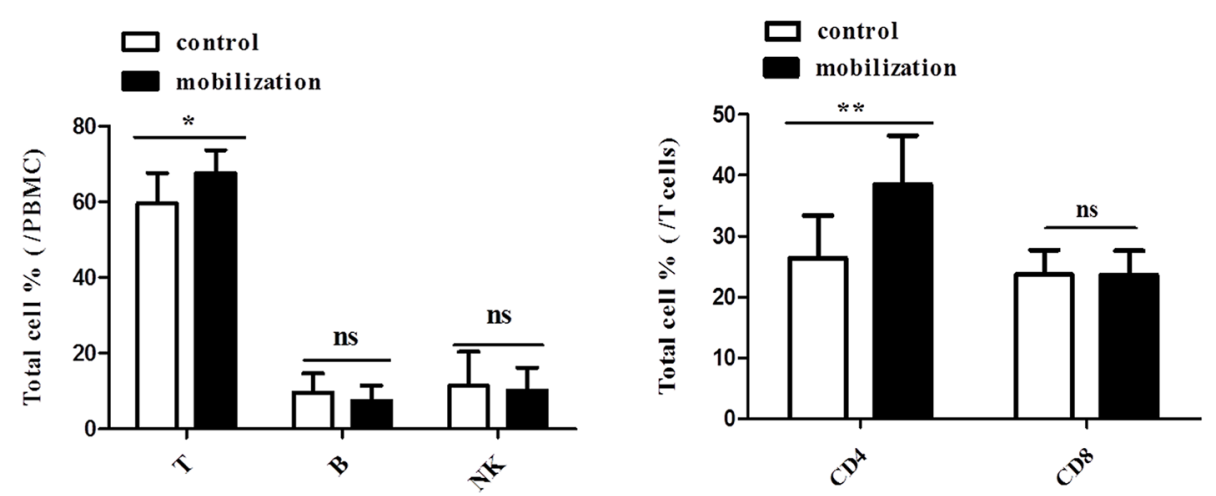

Figure 1: Effect of G-CSF mobilization on lymphocyte and T cell subtypes. (A) PBMCs were collected from healthy volunteers and G-CSF-mobilized donors. Lymphocyte subpopulations were stained with corresponding immunophenotypic markers and analyzed by flow cytometry. (B) The frequency of lymphocyte subsets is summarized in the graph. (C) T cell subpopulations were stained with corresponding fluorescents labeled antibodies and analyzed by flow cytometry. (D) The frequency of T cell subsets is summarized in the graph. Representative flow cytometry images are shown. The data are presented as the mean $\pm \mathrm{SD}(\mathrm{n}=10$ per group). ns: no significant difference; $* P<0.05 ; * * P<0.01$. 


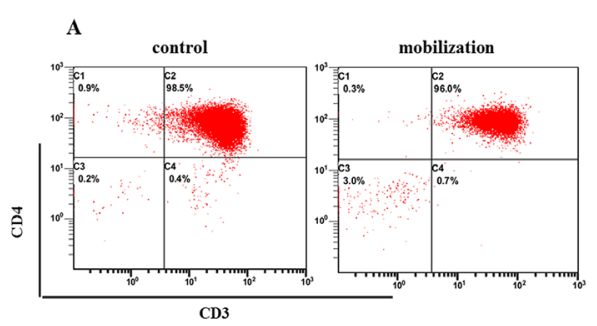

B

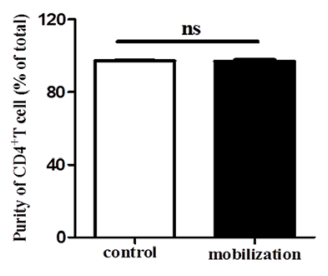

C

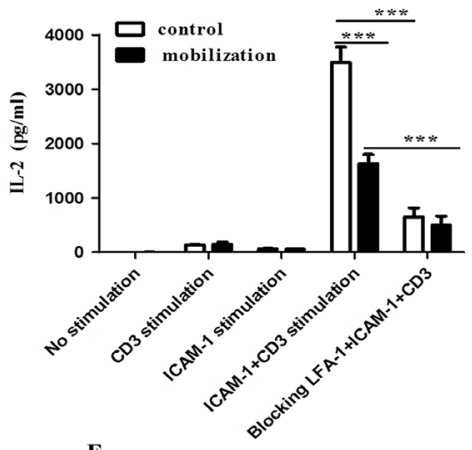

D
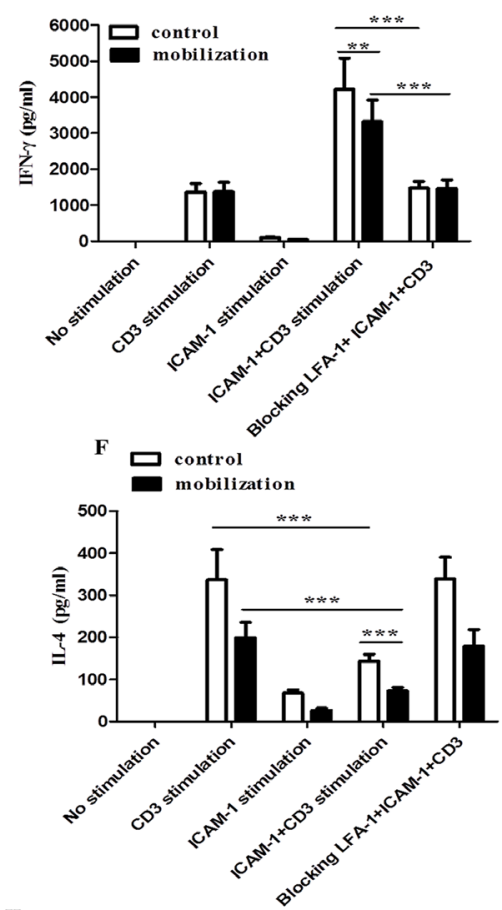

G
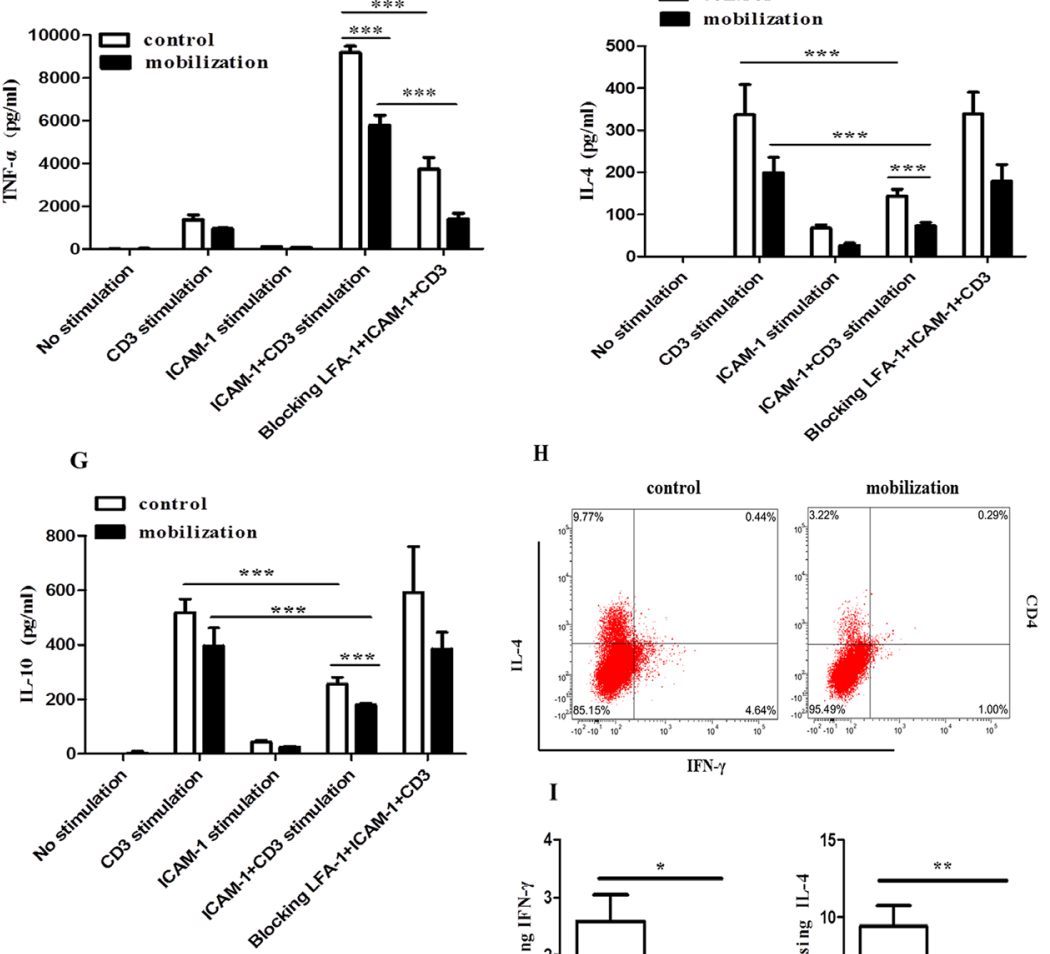

I
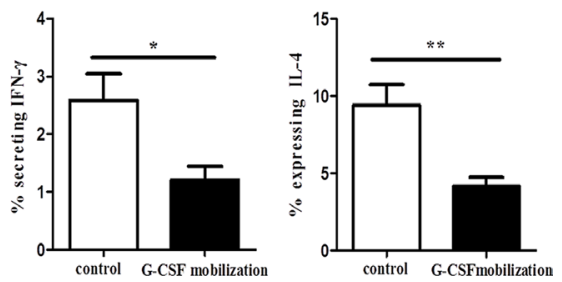

Figure 2: G-CSF mobilization inhibited the secretion of inflammatory cytokines from $\mathbf{C D 4}+\mathbf{T}$ cells. $\mathrm{CD} 4^{+} \mathrm{T}$ cells were purified from the peripheral blood of healthy volunteers and G-CSF-mobilized donors. $\mathrm{CD} 4^{+} \mathrm{T}$ cells were isolated using magnetic beads conjugated to a human CD4 antibody. (A) The purity of the isolated cells was then analyzed by flow cytometry. (B) The purified cells from the two groups were quantified ( $\mathrm{n}=15$ per group).Unstimulated, and ICAM-1-stimulated $\mathrm{CD} 4^{+} \mathrm{T}$ cells from G-CSF-mobilized donors and healthy volunteers were cultured with or without anti-CD3 or ICAM-1 plus anti-CD3 for an additional $72 \mathrm{~h}$. To inhibit LFA-1mediated signalings, the cells were treated with anti-LFA-1 blocking Ab. At the end of the incubation period, the culture supernatants were harvested, and the secreted levels of IL-2 (C), IFN- $\gamma(\mathbf{D})$, TNF- $\alpha(\mathbf{E})$, IL-4 (F) and IL-10 (G) were analyzed by the ProcartaPlex ${ }^{\mathrm{TM}}$ Multiplex Immunoassay ( $\mathrm{n}=13$ per group). (H) IFN- $\gamma$ and IL-4 production by $\mathrm{CD} 4^{+} \mathrm{T}$ cells, evaluated by intracellular IFN- $\gamma$ and IL-4 staining. (I) The percentage of IFN- $\gamma$ and IL-4 expression is summarized in the graph ( $\mathrm{n}=8$ per group). The data are shown as the mean \pm SD. ns: no significant difference; $* P<0.05 ; * * P<0.01 ; * * * P<0.001$. 
un-stimulated (control group) or stimulated with G-CSF (G-CSF group) or G-CSF plus ConA (G-CSF+ConA group) in vitro. There was an approximately 2-fold increase in levels of G-CSFR expression on $\mathrm{CD}^{+} \mathrm{T}$ cells in G-CSF+ConA group compared with control and G-CSF group $(10 \%, 6.13 \%, 6.26 \%$, respcetively) (Figure 4A and 4B). This result indicated that ConA could induce G-CSFR expression in $\mathrm{CD}^{+} \mathrm{T}$ cells. We next determined whether the observed decrease in polarization was a direct effect of G-CSF on $\mathrm{CD}^{+} \mathrm{T}$ cells. Although both unstimulated and G-CSF-stimulated CD4 ${ }^{+} \mathrm{T}$ cells exhibited polarization morphology (Figure 4C), the percentage of polarized cells was significantly lower in the G-CSF group than in the control group $(25.70 \%$ vs. $47.90 \%, P<0.0001)$ (Figure 4D). Moreover, the adhesiveness of the $\mathrm{CD}^{+} \mathrm{T}$ cells in the G-CSF group was also weaker than that of the control group (62.62\% vs. $71.61 \%, P=0.015)$ (Figure 4E). These data suggested that G-CSF could directly inhibit the polarization and adhesiveness of $\mathrm{CD}^{+} \mathrm{T}$ cells.

\section{G-CSF mobilization decreased Lck and ZAP-70 expression on $\mathrm{CD4}^{+} \mathrm{T}$ cells}

Previous studies have demonstrated that LFA-1 engagement in T cells can modulate the activities of signaling proteins, adaptor proteins and enzymes [18, 19, 21, 33]. Lck and ZAP-70 in $\mathrm{CD}^{+} \mathrm{T}$ cells play important roles in both the TCR signal-triggering module and LFA-1/ICAM-1 signaling pathway [34-36]. Then, we explored whether the above-observed G-CSF-mediated inhibition of $\mathrm{CD}^{+} \mathrm{T}$ cell functions was associated with the activation of Lck and ZAP70 in LFA-1 signaling. After stimulated with anti-CD3 and ICAM-1, the levels of phosphorylated Lck and ZAP-70 were significantly lower in the G-CSF mobilized CD4 ${ }^{+} \mathrm{T}$ cells than in the control group $\mathrm{CD}^{+} \mathrm{T}$ cells (Figure $5 \mathrm{~A}-5 \mathrm{D}$ ). In addition, the expressions of total Lck and ZAP-70 were significantly lower in the G-CSF group (Figure 5A and 5B, 5E and 5F). These findings indicated that G-CSF mobilization inhibited LFA-1 signaling by reducing the expression of Lck and ZAP70 , which ultimately inhibited $\mathrm{CD}^{+} \mathrm{T}$ cell functions.
A

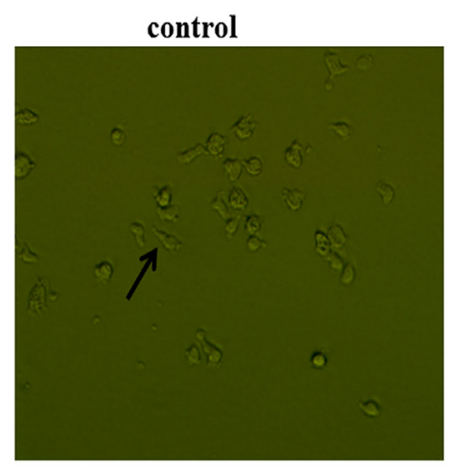

C

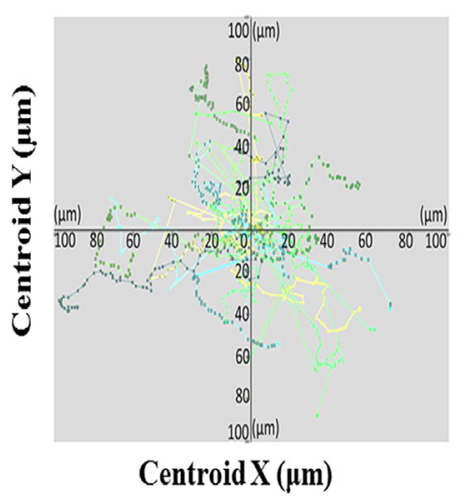

mobilization

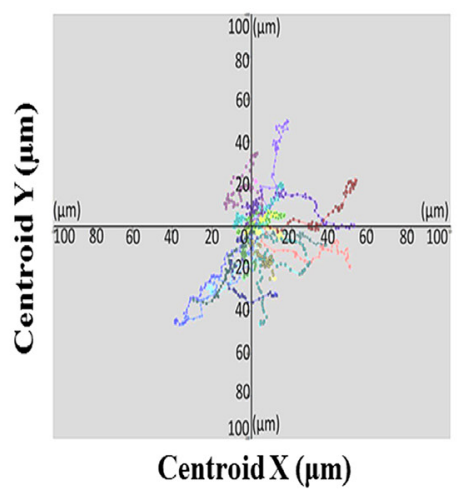

B
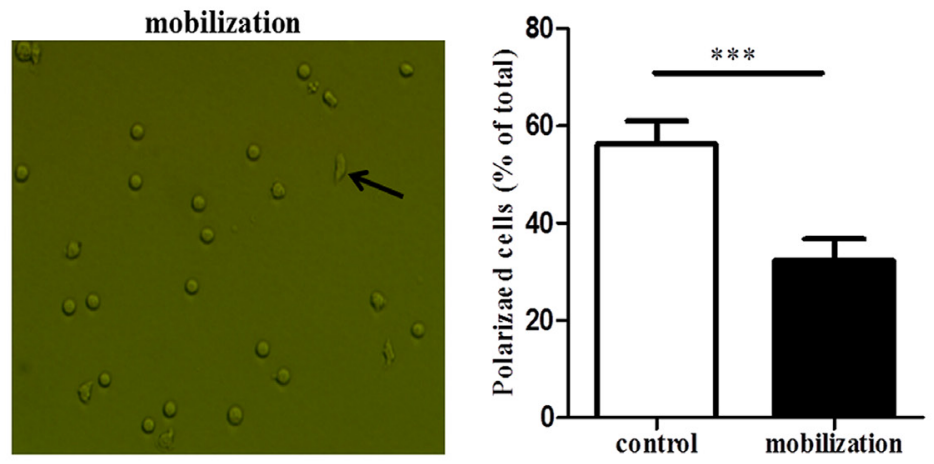

D

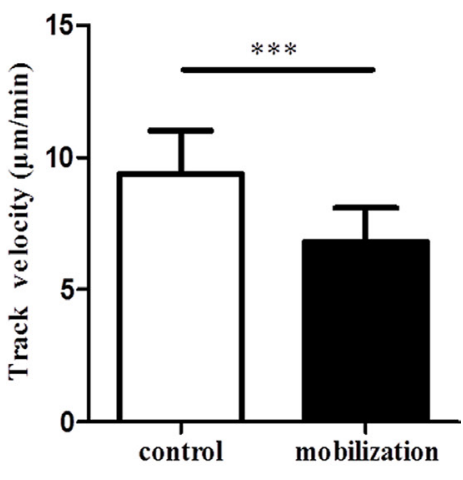

Figure 3: G-CSF reduced the polarization and migration of CD4+ T cells. (A and B) Control and mobilized CD4 ${ }^{+} \mathrm{T}$ cells were added to anti-CD3- and ICAM-1-coated 96-well plates. After incubation at $37^{\circ} \mathrm{C}$ for 60 minutes, the cells were analyzed by fluorescence microscopy. Arrows indicate polarized T cells with a clear uropod. (B) Cells prepared as in A were quantified. (C and D) The two groups of $\mathrm{CD} 4^{+} \mathrm{T}$ cells were loaded on a coated surface, and cell movements were recorded by confocal microscopy. The cell tracks and motility were analyzed by the Velocity software. Tracks of individual cells are presented with the same point of origin. All data are represented as the mean $\pm \mathrm{SD}$ ( $=15$ per group). $* * * P<0.001$. 


\section{G-CSF stimulation reduced the expression of Lck and ZAP-70 in vitro}

Our previous results showed that ConA induced G-CSFR expression in $\mathrm{CD}^{+} \mathrm{T}$ cells. To address whether in vitro stimulation with G-CSF could directly decrease the expression of Lck and ZAP-70 in LFA-1 signaling, CD4 ${ }^{+}$ $\mathrm{T}$ cells were unstimulated (control group) or stimulated with $200 \mathrm{ng} / \mathrm{ml}$ of G-CSF (G-CSF group) or $200 \mathrm{ng} /$ $\mathrm{ml}$ of G-CSF plus $10 \mathrm{ng} / \mathrm{ml}$ of ConA (G-CSF+ConA group) for $24 \mathrm{~h}$. After the stimulation, the cells were transferred to anti-CD3- and ICAM-1-coated 6-well plates

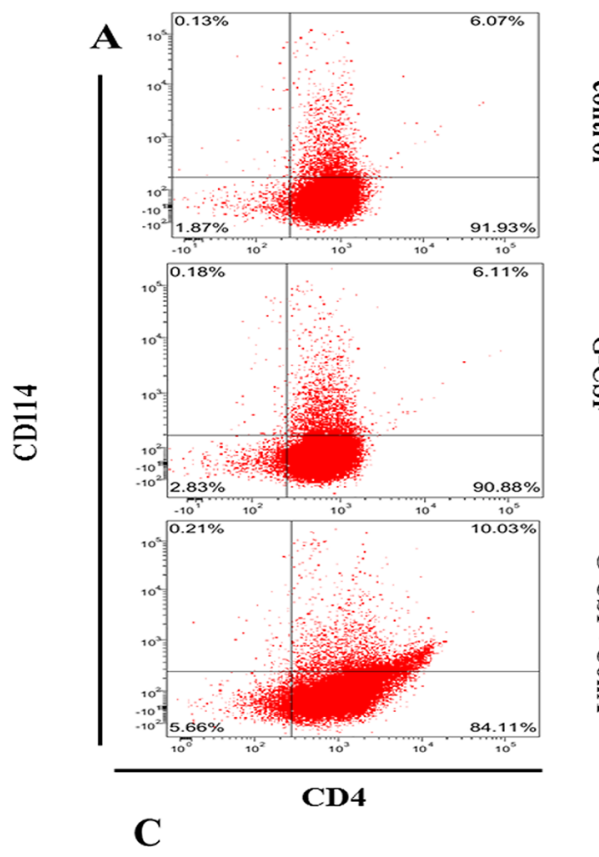

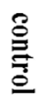

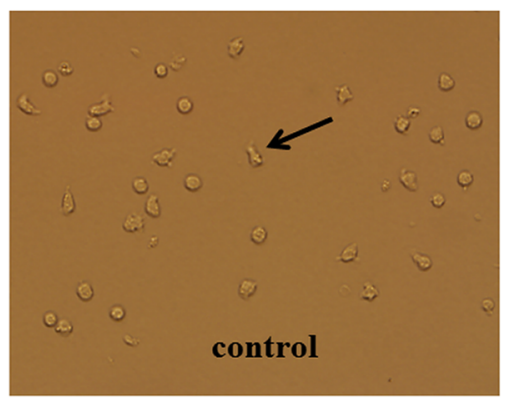

D

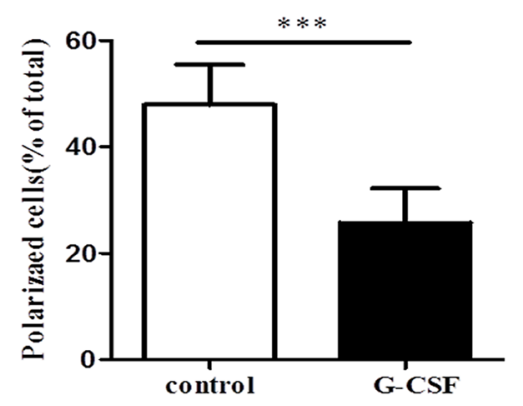

B

$\frac{1}{2}$
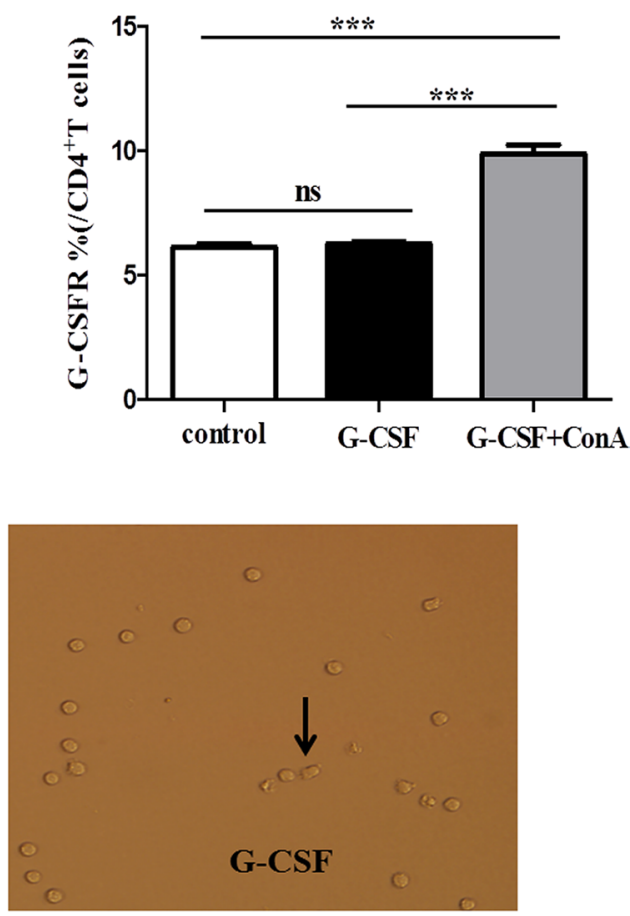

$\mathbf{E}$

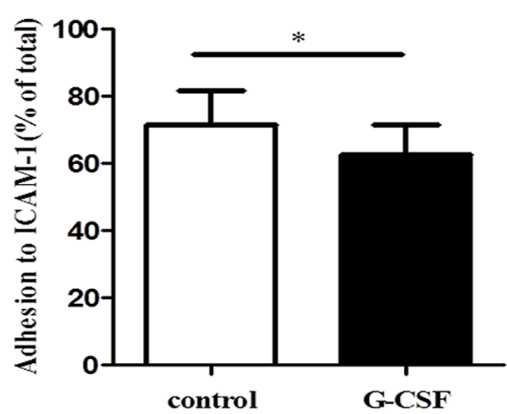

Figure 4: G-CSF attenuated the polarization and adhesion of CD4+ $\mathbf{T}$ cells in vitro. Purified $\mathrm{CD} 4{ }^{+} \mathrm{T}$ cells were added to $24-$ well plates and incubated in RPMI alone or in RPMI containing G-CSF or G-CSF plus ConA for $24 \mathrm{~h}$. (A) The expression of G-CSFR on $\mathrm{CD} 4^{+} \mathrm{T}$ cells, evaluated by CD114 staining. (B) The percentage of G-CSFR is summarized in the graph ( $\mathrm{n}=5$ per group). After incubation 24h, G-CSF stimulated or left un-stimulated CD4 ${ }^{+} \mathrm{T}$ cells were transferred to 96-well plates coated with ICAM-1 and anti-CD3. (C) Cell morphology was examined by fluorescence microscopy at 60 minutes. Arrows indicate polarized T cells with a clear uropod. (D) Cells prepared as in $\mathrm{C}$ were quantified. (E) Unbound cells were washed off, and the adherent cells were quantified using a CCK-8 assay kit. The data are represented as the mean $\pm \mathrm{SD}(\mathrm{n}=15$ per group). $* P<0.05 ; * * * 0.001$. 
and incubated for $1 \mathrm{~h}$ at $37^{\circ} \mathrm{C}$. The results showed that the expressions of Lck and ZAP-70 were significantly lower in the G-CSF stimulated $\mathrm{CD}^{+} \mathrm{T}$ cells than in the unstimulated $\mathrm{CD}^{+} \mathrm{T}$ cells (Figure 6A-6F). Moreover, the total and phosphorylation levels of Lck and ZAP70 were significantly decreased in $\mathrm{G}-\mathrm{CSF}+\mathrm{ConA}$ group
(Figure 6A-6F). These in-vitro results was consistent with the G-CSF mobilization effect above, indicating that G-CSF could inhibit the function of $\mathrm{CD}^{+}{ }^{+} \mathrm{T}$ cells through down-expression of Lck and ZAP-70 in LFA-1 signaling pathway.

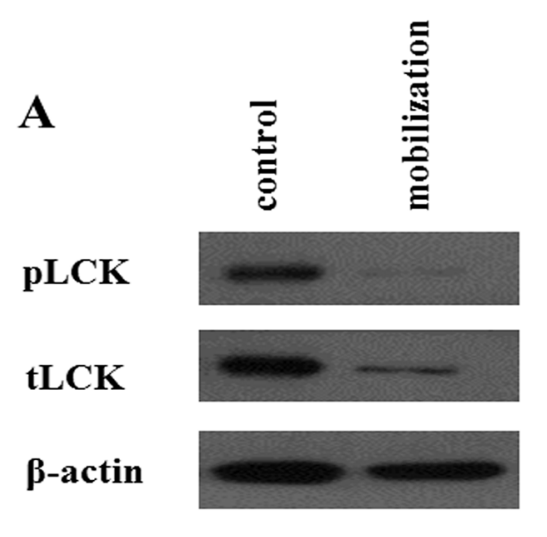

C

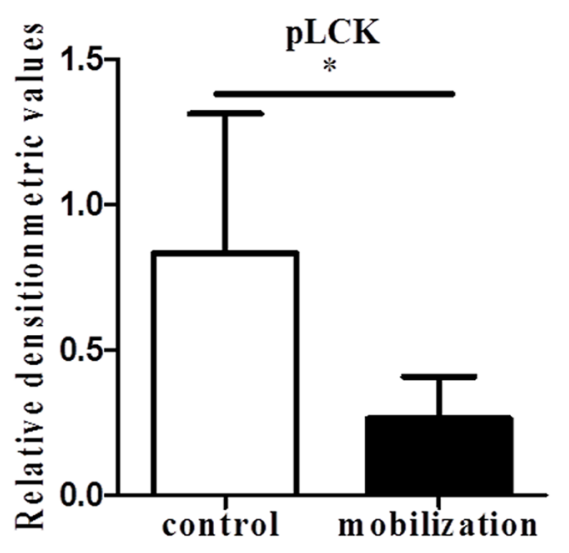

E

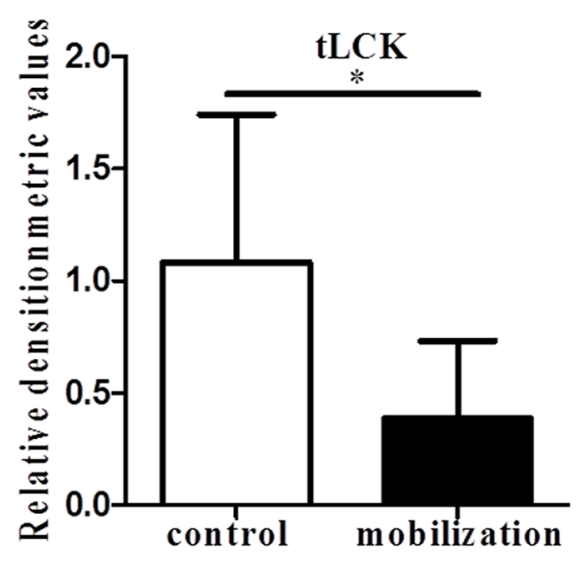

B
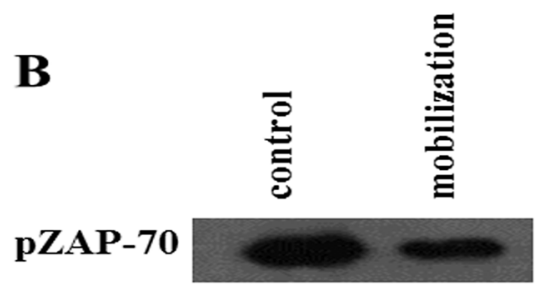

tZAP-70

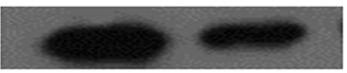

$\beta$-actin

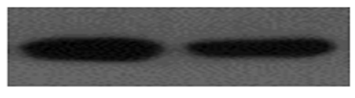

D

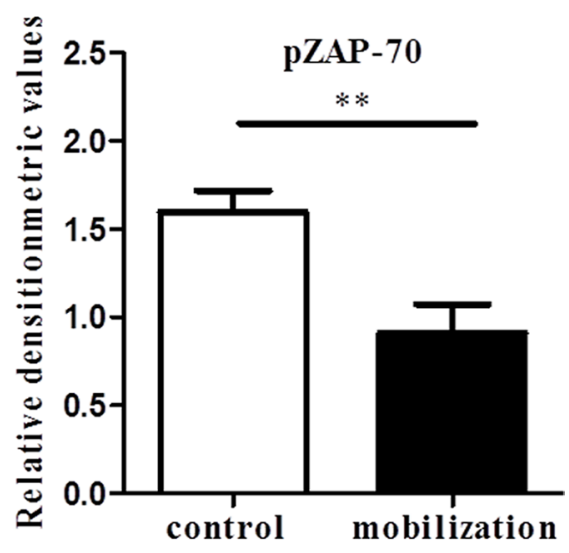

F

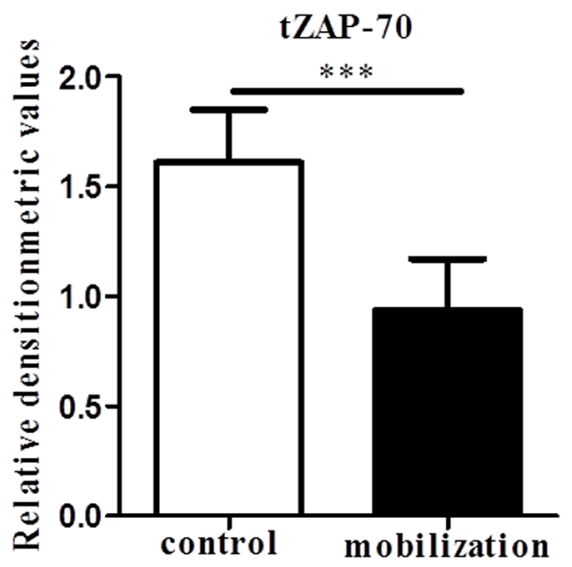

Figure 5: G-CSF decreased the expression of Lck and ZAP-70. Purified control and mobilized CD4 ${ }^{+}$T cells were added to antiCD3- and ICAM-1-coated 6-well plates. After an incubation at $37^{\circ} \mathrm{C}$ for $1 \mathrm{~h}$. (A and $\left.\mathbf{B}\right)$ The cell lysates were analyzed by western blot to detect the expression of Lck, ZAP-70 and phosphorylated Lck and ZAP-70, which were normalized to actin. (C-F) Relative densitometric analysis of the individual protein bands. The data are shown as the mean $\pm \mathrm{SD}$ (n=6 per group). ${ }^{*} P<0.05 ; * * P<0.01 ; * * * P<0.001$. 


\section{DISCUSSION}

We have previously found that G-CSF decreased the proliferation and activation of $\mathrm{CD}^{+} \mathrm{T}$ cells through changing the conformation of LFA-1 [23]. In the present study, we indicated that G-CSF directly suppressed LFA-1-mediated $\mathrm{CD}^{+} \mathrm{T}$ cell functions by inhibiting Lck and ZAP-70. These findings indicated that the immunosuppressive effect of G-CSF on T cells through
LFA-1/ICAM-1 signaling pathway could be a possible target to reduce GVHD.

To investigate why the incidence aGVHD of PBSCT is no higher than that of conventional BMT, most studies focused on the regulatory effects of G-CSF on donor cells in the grafts [37-40]. In this study, we found that G-CSF mobilization could increase the frequency of lymphocytes in the grafts, which was consistent with presvious studies $[27,39,41]$. Specifically, the frequency of $\mathrm{T}$ cells,
$\mathbf{A}$

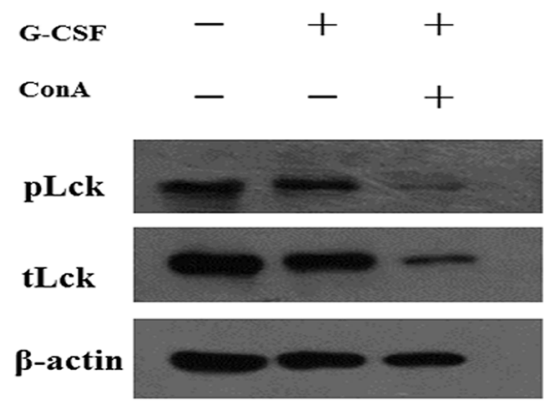

C

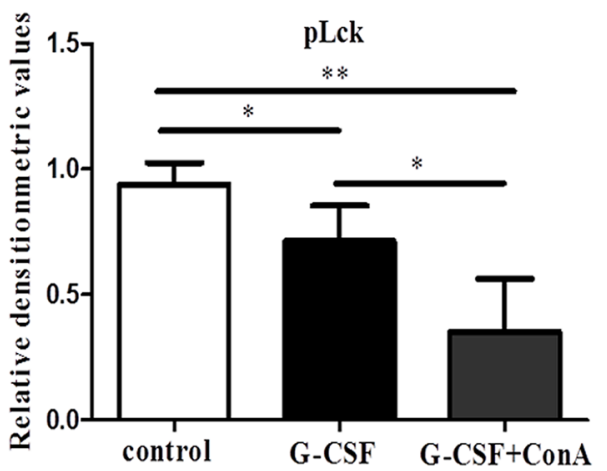

$\mathbf{E}$

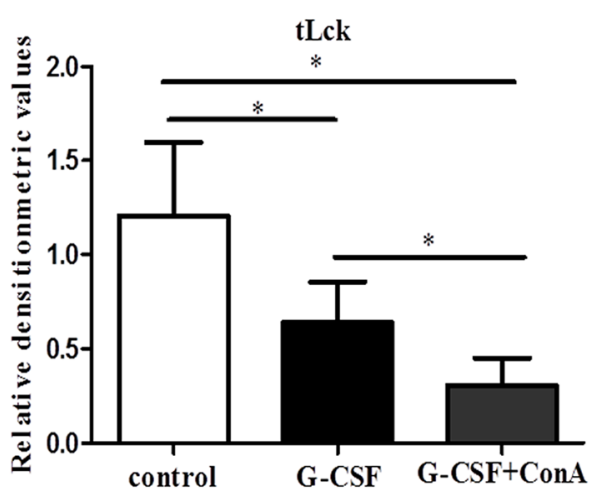

B

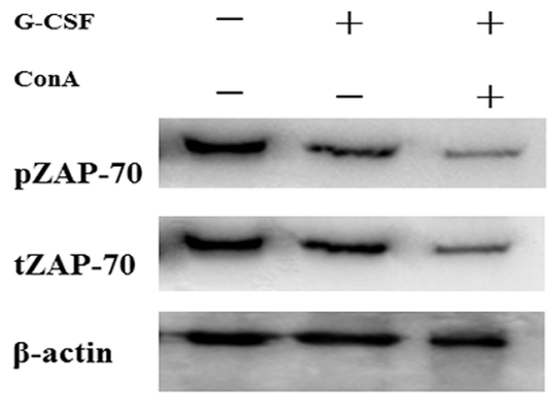

D

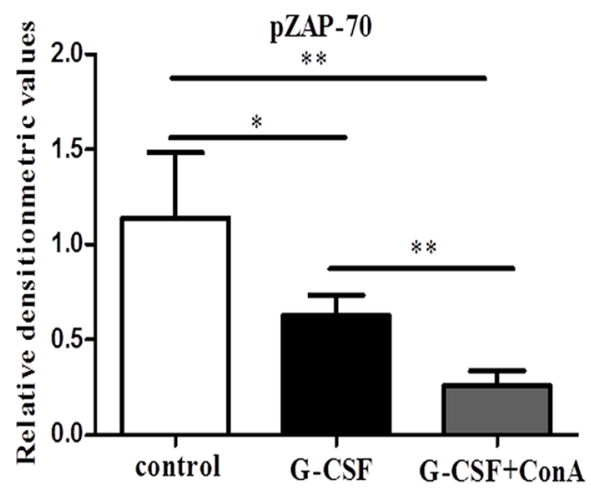

$\mathbf{F}$

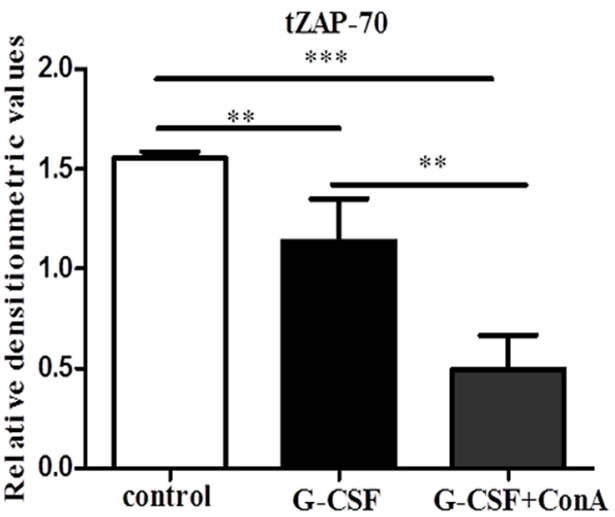

Figure 6: G-CSF stimulation suppressed the expression of Lek and ZAP-70 in vitro. Purified $\mathrm{CD}^{+} \mathrm{T}$ cells were added to 24-well plates and incubated in RPMI alone or in RPMI containing G-CSF or G-CSF plus ConA for $24 \mathrm{~h}$. After the incubation, the cells were transferred to anti-CD3- and ICAM-1-coated 6-well plates and incubated for $1 \mathrm{~h}$ at $37^{\circ} \mathrm{C}$. (A and $\left.\mathbf{B}\right)$ Lysates from the three groups of $\mathrm{CD}^{+} \mathrm{T}$ cells were analyzed by western blot to detect the expression of Lck, ZAP-70 and phosphorylated Lck and ZAP-70, which were normalized to actin. (C-F) Densitometry quantification was performed and presented. All data are represented as the mean $\pm \mathrm{SD}(\mathrm{n}=4$ per group). ${ }^{*} P<0.05 ; * * P<0.01 ; * * * P<0.001$. 
not B cells and NK cells, was increased after G-CSF mobilization. Currently, there are some controversies about the effects of G-CSF mobilization on the frequencies of NK-cell and B-cell [29, 39, 41-43]. Different G-CSF doses may contribute to the discrepancies in these studies. However, the detailed reasons were unclear. Our results showed that the frequency of $\mathrm{CD}^{+} \mathrm{CD} 4^{+} \mathrm{T}$ cells significantly increased in G-CSF-mobilized donors. This observation was in accordance with a previous study [44].

We used MACS kit to isolate $\mathrm{CD}^{+} \mathrm{T}$ cells to avoid interference from other cells, and the purity of $\mathrm{CD}^{+} \mathrm{T}$ cells was greater than $96 \%$. After ICAM-1 and anti-CD3 activation, G-CSF mobilization decreased the levels of several pro-inflammatory cytokines, including IL-2, TNF- $\alpha$ and IFN- $\gamma$, and anti-inflammatory cytokines, such as IL-4 and IL-10. These data are supported by some previous studies [39, 40, 45]. Others studies found that G-CSF increased TH2 cytokine secretion [46, 47]. These discrepancies may due to differences in the sensitivity of the different methods for cytokine detection or to use different reagents in vitro cell stimulation. Moreover, flow cytometric analysis indicated that G-CSF mobilization decreased the percentage of $\mathrm{TH} 1$ and $\mathrm{TH} 2$ cells, but did not alter TH1/TH2 the ratio. The inhibitory effect of G-CSF on cytokine secretion from donor T cells supported the theory that G-CSF attenuated GVHD after PBSC transplantation.

Previous studies had indicated that LFA-1/ ICAM-1 signaling was involved in modulating $\mathrm{T}$ cell functions, including activation and proliferation [48, 49]. In this study, LFA-1 antibody blockade abrogated TH1 polarization, suggesting the important role of LFA1 signaling in $\mathrm{CD}^{+} \mathrm{T}$ cell function. The LFA-1/ICAM1 interaction initiates immune responses through the migration of $\mathrm{T}$ cells toward inflamed tissues or secondary lymphoid organs. The migration of $\mathrm{T}$ cells includes a sequence of rolling, arrest, firm adhesion, polarization and diapedesis $[13,14,18,50]$. Our results demonstrated that G-CSF inhibited LFA-1-mediated $\mathrm{CD}^{+} \mathrm{T}$ cell adhesion, polarization and migration, which may explain previously reported transient defects in the T-cell-mediated immune response [31]. The immunosuppressive effect of G-CSF on T cells may explain why G-CSF mobilized PBSCT has comparable incidence and severity of GVHD with BMT, even though PBSCT contains 10 times more T cells than BMT.

Our in vitro results, where purified $\mathrm{CD}^{+} \mathrm{T}$ cells were stimulated with G-CSF, supported the idea of direct interaction between G-CSF and G-CSFR-positive T cells. Previous studies also indicated that activated $\mathrm{CD}^{+} \mathrm{T}$ and $\mathrm{CD}^{+} \mathrm{T}$ cells can express the G-CSFR $[31,32,46]$. Furthermore, Bunse et al. showed that G-CSF greatly affect the activities of cytotoxic $\mathrm{CD}^{+}$cells and $\mathrm{CD} 4^{+} \mathrm{T}$ cells [51], which indicated that G-CSF may have direct effects on these cells. Src kinases have been shown to play a major role in the G-CSFR signaling pathways
[52, 53]. Borneo and colleagues [54] showed that a Src family kinase negatively regulated hematopoietic stem cell mobilization. Lck, a Src kinase, induces Lckdependent phosphorylation of ZAP-70 following TCR triggering, which leads to the phosphorylation of downstream adaptors, up-regulation of integrin affinity signaling molecules and the activation of LFA-1 [35, $36,55,56]$. We hypothesized that the G-CSF/G-CSFR signaling pathway may first inhibit the expression of the Lck and then down-regulate downstream kinases, adaptors and signaling molecules. Then, this signaling pathway changes the conformation of LFA-1, which ultimately inhibits $\mathrm{CD}^{+} \mathrm{T}$ cell functions. Understanding the potential immunosuppressive effect of G-CSF on donor $\mathrm{T}$ cells could provide an experimental foundation for the translation of this therapeutic target to clinic. Based on our results, it can be speculated that a target of the kinase Lck may be critical for the immunosuppressive effect of $\mathrm{G}-\mathrm{CSF}$ on $\mathrm{CD}^{+} \mathrm{T}$ cell functions.

In conclusion, our study provides new mechanistic insight about the immunomodulatory effects of G-CSF on $\mathrm{CD}^{+} \mathrm{T}$ cell function. Our results indicated that G-CSF directly inhibited LFA-1-mediated $\mathrm{CD}^{+} \mathrm{T}$ cell functions by inhibiting Lck and ZAP-70. The immunosuppressive effect of G-CSF mobilization on donor $\mathrm{CD}^{+} \mathrm{T}$ cells deepened our understanding about PBSCT. LFA-1/ICMA1 pathway may become a potential target for GVHD prophylaxis.

\section{MATERIALS AND METHODS}

\section{Antibodies and reagents}

RPMI 1640, FBS, streptomycin and penicillin were obtained from Gibco Life Technologies (Gibco, Carlsbad, CA, USA). Ficoll-Paque PLUS was obtained from GE Healthcare Life Sciences (GE, Pittsburgh, PA, USA). PBS was purchased from Solarbio Life Sciences (Solarbio, Beijing, China). BSA was obtained from Sigma Aldrich (Sigma, St Louis, MO, USA). Magnetic beads conjugated with an anti-CD4 monoclonal antibody were purchases from Miltenyi Biotec (Miltenyi, Cologne, Germany). PerCP-conjugated anti-CD45, PE/FITC-conjugated anti-CD3, PE/PE-Cy5- conjugated anti-CD4, PE-Cy5conjugated anti-CD8, FITC-conjugated anti-CD19, FITC/PE-Cy5-conjugated anti-CD56, FITC-conjugated anti-IFN- $\gamma$, PE-conjugated anti-IL-4, PE-conjugated anti-CD114, the anti-LFA-1 blocking Ab and anti-CD3 monoclonal antibody were obtained from Biolegend (Biolegend, San Diego, CA, USA). The recombinant human ICAM-1/CD54 Fc chimera was from R\&D Systems Inc. (RD, Minneapolis, MN, USA). Fluo4-AM and CCK-8 were obtained from Dojindo Laboratories (Dojindo, Osaka, Japan). Human IFN- $\gamma$, IL-2, IL-4, IL-10 and TNF- $\alpha$ were obtained from eBioscience (eBioscience, San Diego, CA, USA). Concanavalin A (ConA) was 
purchased from Santa Cruz Biotechnology (Santa Cruz, Dallas, TX, USA). G-CSF was provided by PLA General Hospital (Kirin Kunpeng, Shanghai, China). Antibodies against ZAP-70 (\#3165P) and phospho-ZAP-70 (Y319) (\#2701P) were purchased from Cell Signaling Technology Inc. (Cell Signaling Technology, Danvers, MA, USA). Antibodies against Lck (SC-166627), phospho-Lck (Tyr394) (SC-101728) and $\beta$-actin (SC-47778) were purchased from Santa Cruz Biotechnology (Santa Cruz, Dallas, TX, USA). Anti-rabbit and anti-mouse IgG were obtained from Santa Cruz Biotechnology (Santa Cruz, Dallas, TX, USA). The enhanced chemiluminescence (ECL) detection reagent was from GE Healthcare Life Sciences (GE, Pittsburgh, PA, USA).

\section{Sample collection and processing}

Peripheral blood was collected from healthy volunteers (normal controls) or G-CSF mobilized donors (10 $\mu \mathrm{g} / \mathrm{kg}$ daily for 5 days). Peripheral blood mononuclear cells (PBMCs) were isolated from whole blood by density gradient centrifugation with Ficoll-Paque ${ }^{\mathrm{TM}}$. This study was reviewed and approved by the Medical Ethics Committee of PLA General Hospital.

\section{Isolation and purity of $\mathrm{CD}^{+} \mathrm{T}$ cells}

Human $\mathrm{CD}^{+} \mathrm{T}$ cells were isolated by positive immunomagnetic selection by exposing PBMCs to magnetic beads conjugated with an anti-CD4 monoclonal antibody prior to separation with a magnetic cell sorter (MACS). The isolated CD4 ${ }^{+} \mathrm{T}$ cells were stained with FITC-conjugated anti-CD3 and PE-conjugated anti-CD4 mAbs. The purity of the stained cells was detected using a flow cytometer. Freshly purified $\mathrm{CD} 4^{+} \mathrm{T}$ cells were then cultured in RPMI 1640 supplemented with 10\% FBS and $1 \%$ streptomycin and penicillin at $37^{\circ} \mathrm{C}$ in a $5 \% \mathrm{CO}_{2}$ atmosphere.

\section{Lymphocyte and $T$ cell subtype analysis}

PBMCs were separated from the whole blood of healthy volunteers and G-CSF- mobilized donors using density gradient centrifugation with Ficoll-Paque ${ }^{\mathrm{TM}}$. Lymphocytes subpopulations, including T cells, B cells and $\mathrm{NK}$ cells, and $\mathrm{T}$ cell subpopulations, including $\mathrm{CD}^{+} \mathrm{CD}^{+}$and $\mathrm{CD}^{+}{ }^{+} \mathrm{CD}^{+} \mathrm{T}$ cells, were stained with the corresponding fluorescently labeled antibodies. The stained cells were detected using a flow cytometer (Becton Dickinson), and the data were analyzed using CXP Analysis 2.1.

\section{Cytokine measurements}

Freshly isolated $\mathrm{CD}^{+} \mathrm{T}$ cells from healthy volunteers and G-CSF mobilized donors were stimulated with ICAM-1 or left un-stimulated and then cultured with or without an anti-CD3 mAb $(5 \mu \mathrm{g} / \mathrm{ml})$ or ICAM-1 $(3 \mu \mathrm{g} /$ $\mathrm{ml})$ plus an anti-CD3 $\mathrm{mAb}(5 \mu \mathrm{g} / \mathrm{ml})$ for an additional $72 \mathrm{~h}$ at $37^{\circ} \mathrm{C}$ in a $5 \% \mathrm{CO}_{2}$ incubator. To inhibit LFA-1-mediated signalings, the cells were treated with anti-LFA-1 blocking Ab $(100 \mu \mathrm{g} / \mathrm{ml})$. The levels of IL-2, IFN- $\gamma$, TNF- $\alpha$, IL-4 and IL-10 secreted into the CD4 ${ }^{+} \mathrm{T}$ cell culture supernatant were measured by the ProcartaPlex ${ }^{\text {TM }}$ Multiplex immunoassay according to the manufacturer's instructions.

\section{Intracellular staining}

After a $72 \mathrm{~h}$ culture at $37^{\circ} \mathrm{C}$ in a $5 \% \mathrm{CO}_{2}$ incubator, in the presence of ICAM- $1(3 \mu \mathrm{g} / \mathrm{ml})$ and anti-CD3 mAb (5 $\mu \mathrm{g} / \mathrm{ml}), \mathrm{CD}^{+} \mathrm{T}$ cells from healthy volunteers and G-CSFmobilized donors labeled with a PE-Cy5-conjugated CD4 $\mathrm{mAb}$ and fixed. After membrane permeabilization, the cells were stained with FITC-conjugated anti-IFN- $\gamma$ and PE-conjugated anti-IL-4 mAbs. After washing, the cells were fixed and analyzed by a flow cytometer.

\section{Polarization assay}

The polarization assay was carried out in 96-well plates as described elsewhere [33, 57, 58]. The 96-well plates were pre-coated overnight at $4{ }^{\circ} \mathrm{C}$ with $3 \mu \mathrm{g} / \mathrm{ml}$ ICAM-1-Fc and $5 \mu \mathrm{g} / \mathrm{ml}$ anti-CD3 $\mathrm{mAb}$ in PBS buffer. Then, the wells were blocked with $2.5 \%$ BSA-PBS for $2 \mathrm{~h}$ at $37^{\circ} \mathrm{C}$ and washed twice with RPMI 1640. Next, $\mathrm{CD}^{+} \mathrm{T}$ cells $\left(8 \times 10^{4}\right.$ cells per well $)$ were added to the wells, followed by incubation of the plates for 20 minutes at $37^{\circ} \mathrm{C}$. Then, the unbound cells were gently washed off, RPMI 1640 was added to the wells, and the plates were then incubated for another 40 minutes at $37^{\circ} \mathrm{C}$. The polarized cells were analyzed by fluorescence microscopy.

\section{Confocal microscopy}

Small round glass confocal dishes $13 \mathrm{~mm}$ in diameter were pre-coated with ICAM-1Fc $(3 \mu \mathrm{g} / \mathrm{ml})$ and an anti-CD3 $\mathrm{mAb}(5 \mu \mathrm{g} / \mathrm{ml})$ in PBS overnight at $4^{\circ} \mathrm{C}$. The small confocal dishes were blocked with $2.5 \%$ BSA in PBS for $2 \mathrm{~h}$ at $37^{\circ} \mathrm{C}$ in a $5 \% \mathrm{CO}_{2}$ atmosphere. The dishes were washed three times with PBS. Then, Fluo4-AM $(1 \mathrm{mmol} / \mathrm{L})$ was added to the $\mathrm{CD}^{+} \mathrm{T}$ cells, which were then incubated at $37^{\circ} \mathrm{C}$ in a $5 \% \mathrm{CO}_{2}$ atmosphere for 30 minutes and then transferred to the coated small confocal dishes and incubated for 20 minutes at $37^{\circ} \mathrm{C}$. Finally, the images and track velocity were captured on a Perkin Elmer confocal microscope equipped with a real-time imaging analysis system.

\section{G-CSFR expression analysis}

Purified $\mathrm{CD}^{+} \mathrm{T}$ cells $\left(1 \times 10^{6}\right.$ cells per well $)$ from healthy volunteers were added to 24-well plates and incubated in RPMI alone (control group) or in RPMI 
containing $200 \mathrm{ng} / \mathrm{ml} \mathrm{G-CSF}$ (G-CSF group) or $200 \mathrm{ng} / \mathrm{ml}$ G-CSF plus $10 \mu \mathrm{g} / \mathrm{ml}$ ConA (G-CSF+ConA group) for 24 $\mathrm{h}$ at $37^{\circ} \mathrm{C}$ in a $5 \% \mathrm{CO}_{2}$ atmosphere. After the incubation, cells were stained with PE-Cy5-conjugated anti-CD4 and PE-conjugated anti-CD114 mAbs. After washing, the cells were fixed and analyzed by a flow cytometer.

\section{In vitro adhesion assay}

Briefly, 96-well plastic dishes were pre-coated as described above. The isolated $\mathrm{CD}^{+} \mathrm{T}$ cells $\left(5 \times 10^{5}\right.$ cells per well) were seeded into 24 -well plates with or without $200 \mathrm{ng} / \mathrm{ml} \mathrm{G}-\mathrm{CSF}$, followed by incubation for $24 \mathrm{~h}$ at $37^{\circ} \mathrm{C}$ in a $5 \% \mathrm{CO}_{2}$ atmosphere. The cells were then added to the anti-CD3- and ICAM-1-coated wells, and the plates were incubated for $3 \mathrm{~h}$ at $37^{\circ} \mathrm{C}$. The attachment assay was carried out using a CCK- 8 assay kit according to the manufacturer's instructions.

\section{Western blot analysis}

Purified CD4 ${ }^{+} \mathrm{T}$ cells $\left(1 \times 10^{6}\right.$ cells per well $)$ from the control group and G-CSF-mobilization group were added to anti-CD3- and ICAM-1-coated 6-well plates and incubated for $1 \mathrm{~h}$ at $37^{\circ} \mathrm{C}$. For the in vitro assay, purified $\mathrm{CD}^{+} \mathrm{T}$ cells $\left(1 \times 10^{6}\right.$ cells per well $)$ from healthy volunteers were added to 24-well plates and incubated in RPMI alone or in RPMI containing $200 \mathrm{ng} / \mathrm{ml} \mathrm{G-CSF}$ or $200 \mathrm{ng} / \mathrm{ml} \mathrm{G}-\mathrm{CSF}$ plus $10 \mu \mathrm{g} / \mathrm{ml}$ ConA for $24 \mathrm{~h}$. After the incubation, cells were transferred to anti-CD3- and ICAM1-coated 6-well plates and incubated at $37^{\circ} \mathrm{C}$ for $1 \mathrm{~h}$. Then $\mathrm{CD}^{+} \mathrm{T}$ cells were then harvested and lysed in lysis buffer for 30 minutes on ice. Then, $5 \times$ SDS loading buffer was added, and the samples were denatured. Lysates from each sample were separated by $8 \%$ SDS-PAGE and transferred to PVDF membranes. The membranes were blocked with $5 \%$ non-fat milk and probed overnight at $4{ }^{\circ} \mathrm{C}$ with the following primary antibodies: anti-ZAP-70 (dilution, 1:1000), anti-Lck (dilution, 1:200), anti-phos-pho-ZAP-70 (dilution, 1:1000), anti-phospho-Lck (dilution, 1:200) and anti- $\beta$-actin (dilution, 1:500). Then, the membranes were incubated with horseradish peroxidase-conjugated secondary antibodies (anti-rabbit or anti-mouse IgG, 1:2000) for 45 minutes at room temperature. After washing, the blots were developed using an ECL detection reagent. Densitometric analyses of the western blots were performed using Image $\mathbf{J}$ software.

\section{Statistical analysis}

The Data are presented as the means \pm standard deviation (SD), and the significance of differences was determined using unpaired and paired Student's t tests (GraphPad Prism software, version 5, USA). Significant differences were indicated as follows: ${ }^{*}, P<0.05 ; * *, P<$ $0.01 ; * * *, P<0.001$.

\section{ACKNOWLEDGMENTS}

The authors would like to thank Na Lv and Yonghui Li for their technical assistance and Kai Wang for help with the confocal microscope.

\section{CONFLICTS OF INTEREST}

The authors declare that they have no competing interests.

\section{GRANT SUPPORT}

This work was supported by grants from the National Natural Science Foundation of China (81070451; 81270642) and the Social Development of Hainan Province Special Fund Project of Science and Technology (SF201306).

\section{REFERENCES}

1. Bendall LJ, Bradstock KF. G-CSF: from granulopoietic stimulant to bone marrow stem cell mobilizing agent. Cytokine Growth Factor Rev. 2014; 25:355-67.

2. Panopoulos AD, Watowich SS. Granulocyte colonystimulating factor: molecular mechanisms of action during steady state and 'emergency' hematopoiesis. Cytokine. 2008; 42:277-88.

3. Anderlini P, Champlin RE. Biologic and molecular effects of granulocyte colony-stimulating factor in healthy individuals: recent findings and current challenges. Blood. 2008; 111:1767-72.

4. Fukuzono S, Kato T, Fujita H, Watanabe N, Kitagawa S. Granulocyte colony-stimulating factor negatively regulates Toll-like receptor agonist-induced cytokine production in human neutrophils. Arch Biochem Biophys. 2010; 495:144-51.

5. Rutella S, Zavala F, Danese S, Kared H, Leone G. Granulocyte colony-stimulating factor: a novel mediator of T cell tolerance. J Immunol. 2005; 175:7085-91.

6. Ferrara JL, Levine JE, Reddy P, Holler E. Graft-versus-host disease. Lancet. 2009; 373:1550-61.

7. Shlomchik WD. Graft-versus-host disease. Nat Rev Immunol. 2007; 7:340-52.

8. Bleakley M, Riddell SR. Exploiting T cells specific for human minor histocompatibility antigens for therapy of leukemia. Immunol Cell Biol. 2011; 89:396-407.

9. Choi J, Ritchey J, Prior JL, Holt M, Shannon WD, Deych E, Piwnica-Worms DR, DiPersio JF. In vivo administration of hypomethylating agents mitigate graft-versus-host disease without sacrificing graft-versus-leukemia. Blood. 2010; 116:129-39. 
10. Zhang Y, Zhang Y, Gu W, He L, Sun B. Th1/Th2 cell's function in immune system. Adv Exp Med Biol. 2014; 841:45-65.

11. Lafaille JJ. The role of helper $T$ cell subsets in autoimmune diseases. Cytokine Growth Factor Rev. 1998; 9:139-51.

12. Schulze-Koops H, Kalden JR. The balance of Th1/Th2 cytokines in rheumatoid arthritis. Best Pract Res Clin Rheumatol. 2001; 15:677-91.

13. Evans R, Patzak I, Svensson L, De Filippo K, Jones K, McDowall A, Hogg N. Integrins in immunity. J Cell Sci. 2009; 122:215-25.

14. Smith A, Stanley P, Jones K, Svensson L, McDowall A, Hogg N. The role of the integrin LFA-1 in T-lymphocyte migration. Immunol Rev. 2007; 218:135-46.

15. Springer TA. Traffic signals for lymphocyte recirculation and leukocyte emigration: the multistep paradigm. Cell. 1994; 76:301-14.

16. Shimizu Y. LFA-1: more than just $\mathrm{T}$ cell Velcro. Nat Immunol. 2003; 4:1052-4.

17. Pribila JT, Quale AC, Mueller KL, Shimizu Y. Integrins and T cell-mediated immunity. Annu Rev Immunol. 2004; 22:157-80.

18. Hogg N, Patzak I, Willenbrock F. The insider's guide to leukocyte integrin signalling and function. Nat Rev Immunol. 2011; 11:416-26.

19. Ong ST, Freeley M, Skubis-Zegadlo J, Fazil MH, Kelleher D, Fresser F, Baier G, Verma NK, Long A. Phosphorylation of Rab5a protein by protein kinase $\mathrm{C}$ is crucial for T-cell migration. J Biol Chem. 2014; 289:19420-34.

20. Verma NK, Dempsey E, Long A, Davies A, Barry SP, Fallon PG, Volkov Y, Kelleher D. Leukocyte function-associated antigen-1/intercellular adhesion molecule-1 interaction induces a novel genetic signature resulting in T-cells refractory to transforming growth factor-beta signaling. J Biol Chem. 2012; 287:27204-16.

21. Verma NK, Kelleher D. Adaptor regulation of LFA-1 signaling in T lymphocyte migration: potential druggable targets for immunotherapies? Eur J Immunol. 2014; 44:3484-99.

22. Volkov Y, Long A, McGrath S, Ni Eidhin D, Kelleher D. Crucial importance of PKC-beta(I) in LFA-1-mediated locomotion of activated T cells. Nat Immunol. 2001; 2:508-14.

23. Weihua C, Fei W, Meng L, Haiyan Z, Wanming D, Chunji G. The effect of rhG-CSF on the conformation of LFA-1 on $\mathrm{CD}^{+} \mathrm{T}$ cells in hemopoietic stem cell transplantation. Immunopharmacol Immunotoxicol. 2009; 31:267-73.

24. Blaise D, Kuentz M, Fortanier C, Bourhis JH, Milpied N, Sutton L, Jouet JP, Attal M, Bordigoni P, Cahn JY, Boiron JM, Schuller MP, Moatti JP, et al. Randomized trial of bone marrow versus lenograstim-primed blood cell allogeneic transplantation in patients with early-stage leukemia: a report from the Societe Francaise de Greffe de Moelle. J Clin Oncol. 2000; 18:537-46.
25. Korbling M, Przepiorka D, Huh YO, Engel H, van Besien K, Giralt S, Andersson B, Kleine HD, Seong D, Deisseroth AB, Andreeff M, Champlin R. Allogeneic blood stem cell transplantation for refractory leukemia and lymphoma: potential advantage of blood over marrow allografts. Blood. 1995; 85:1659-65.

26. Mahmoud H, Fahmy O, Kamel A, Kamel M, El-Haddad A, El-Kadi D. Peripheral blood vs bone marrow as a source for allogeneic hematopoietic stem cell transplantation. Bone Marrow Transplant. 1999; 24:355-8.

27. Dreger P, Haferlach T, Eckstein V, Jacobs S, Suttorp M, Loffler H, Muller-Ruchholtz W, Schmitz N. G-CSFmobilized peripheral blood progenitor cells for allogeneic transplantation: safety, kinetics of mobilization, and composition of the graft. Br J Haematol. 1994; 87:609-13.

28. Singhal S, Powles R, Kulkarni S, Treleaven J, Sirohi B, Millar B, Shepherd V, Saso R, Rowland A, Long S, Cabral S, Horton C, Mehta J. Comparison of marrow and blood cell yields from the same donors in a double-blind, randomized study of allogeneic marrow vs blood stem cell transplantation. Bone Marrow Transplant. 2000; 25:501-5.

29. Weaver $\mathrm{CH}$, Longin $\mathrm{K}$, Buckner $\mathrm{CD}$, Bensinger W. Lymphocyte content in peripheral blood mononuclear cells collected after the administration of recombinant human granulocyte colony-stimulating factor. Bone Marrow Transplant. 1994; 13:411-5.

30. Verma NK, Fazil MH, Ong ST, Chalasani ML, Low JH, Kottaiswamy A, Praseetha P, Kizhakeyil A, Kumar S, Panda AK, Freeley M, Smith SM, Boehm BO, et al. LFA-1/ICAM-1 ligation in human T cells promotes Th1 polarization through a GSK3beta signaling-dependent Notch pathway. J Immunol. 2016; 197:108-18.

31. Franzke A, Piao W, Lauber J, Gatzlaff P, Konecke C, Hansen W, Schmitt-Thomsen A, Hertenstein B, Buer J, Ganser A. G-CSF as immune regulator in T cells expressing the G-CSF receptor: implications for transplantation and autoimmune diseases. Blood. 2003; 102:734-9.

32. Morikawa K, Morikawa S, Nakamura M, Miyawaki T. Characterization of granulocyte colony-stimulating factor receptor expressed on human lymphocytes. Br J Haematol. 2002; 118:296-304.

33. Wang H, Wei B, Bismuth G, Rudd CE. SLP-76-ADAP adaptor module regulates LFA-1 mediated costimulation and T cell motility. Proc Natl Acad Sci U S A. 2009; 106:12436-41.

34. Kaur M, Singh M, Silakari O. Insight into the therapeutic aspects of 'Zeta-Chain Associated Protein Kinase 70 kDa' inhibitors: a review. Cell Signal. 2014; 26:2481-92.

35. Salmond RJ, Filby A, Qureshi I, Caserta S, Zamoyska R. T-cell receptor proximal signaling via the Src-family kinases, Lck and Fyn, influences T-cell activation, differentiation, and tolerance. Immunol Rev. 2009; 228:9-22.

36. Zhang $\mathrm{Y}$, Wang $\mathrm{H}$. Integrin signalling and function in immune cells. Immunology. 2012; 135:268-75. 
37. Joshi SS, Lynch JC, Pavletic SZ, Tarantolo SR, Pirruccello SJ, Kessinger A, Bishop MR. Decreased immune functions of blood cells following mobilization with granulocyte colony-stimulating factor: association with donor characteristics. Blood. 2001; 98:1963-70.

38. Nawa Y, Teshima T, Sunami K, Hiramatsu Y, Maeda Y, Yano T, Shinagawa K, Ishimaru F, Omoto E, Harada M. G-CSF reduces IFN-gamma and IL-4 production by $\mathrm{T}$ cells after allogeneic stimulation by indirectly modulating monocyte function. Bone Marrow Transplant. 2000; 25:1035-40.

39. Tayebi H, Kuttler F, Saas P, Lienard A, Petracca B, Lapierre V, Ferrand C, Fest T, Cahn J, Blaise D, Kuentz M, Herve P, Tiberghien P, et al. Effect of granulocyte colony-stimulating factor mobilization on phenotypical and functional properties of immune cells. Exp Hematol. 2001; 29:458-70.

40. Vasconcelos ZF, Santos BM, Costa ES, Lima M, Tabak DG, Bouzas LF, Azevedo WM, Barcinski MA, Bonomo A. T-lymphocyte function from peripheral blood stem-cell donors is inhibited by activated granulocytes. Cytotherapy. 2003; 5:336-45.

41. Sica S, Rutella S, Di Mario A, Salutari P, Rumi C, Ortu la Barbera E, Etuk B, Menichella G, D'Onofrio G, Leone G. rhG-CSF in healthy donors: mobilization of peripheral hemopoietic progenitors and effect on peripheral blood leukocytes. J Hematother. 1996; 5:391-7.

42. Hartung T, Doecke WD, Bundschuh D, Foote MA, Gantner F, Hermann C, Lenz A, Milwee S, Rich B, Simon B, Volk HD, von Aulock S, Wendel A. Effect of filgrastim treatment on inflammatory cytokines and lymphocyte functions. Clin Pharmacol Ther. 1999; 66:415-24.

43. Rondelli D, Raspadori D, Anasetti C, Bandini G, Re F, Arpinati M, Stanzani M, Morelli A, Baccini C, Zaccaria A, Lemoli RM, Tura S. Alloantigen presenting capacity, T cell alloreactivity and NK function of G-CSF-mobilized peripheral blood cells. Bone Marrow Transplant. 1998; 22:631-7.

44. Martinez C, Urbano-Ispizua A, Rozman C, Marin P, Mazzara R, Carreras E, Rovira M, Sierra J, Briones J, Ordinas A, Montserrat E. Effects of G-CSF administration and peripheral blood progenitor cell collection in 20 healthy donors. Ann Hematol. 1996; 72:269-72.

45. Mielcarek M, Storer B, Martin PJ, Forman SJ, Negrin RS, Flowers ME, Inamoto Y, Chauncey TR, Storb R, Appelbaum FR, Bensinger WI. Long-term outcomes after transplantation of HLA-identical related G-CSF-mobilized peripheral blood mononuclear cells versus bone marrow. Blood. 2012; 119:2675-8.

46. Sloand EM, Kim S, Maciejewski JP, Van Rhee F, Chaudhuri A, Barrett J, Young NS. Pharmacologic doses of granulocyte colony-stimulating factor affect cytokine production by lymphocytes in vitro and in vivo. Blood. 2000; 95:2269-74.

47. Singh RK, Ino K, Varney ML, Heimann DG, Talmadge JE. Immunoregulatory cytokines in bone marrow and peripheral blood stem cell products. Bone Marrow Transplant. 1999; 23:53-62.

48. Koszik F, Stary G, Selenko-Gebauer N, Stingl G. Efalizumab modulates $\mathrm{T}$ cell function both in vivo and in vitro. J Dermatol Sci. 2010; 60:159-66.

49. Reisman NM, Floyd TL, Wagener ME, Kirk AD, Larsen CP, Ford ML. LFA-1 blockade induces effector and regulatory T-cell enrichment in lymph nodes and synergizes with CTLA-4Ig to inhibit effector function. Blood. 2011; 118:5851-61.

50. Kinashi T. Integrin regulation of lymphocyte trafficking: lessons from structural and signaling studies. Adv Immunol. 2007; 93:185-227.

51. Bunse CE, Tischer S, Lahrberg J, Oelke M, Figueiredo C, Blasczyk R, Eiz-Vesper B. Granulocyte colony-stimulating factor impairs CD8+ T-cell functionality by interfering with central activation elements. Clin Exp Immunol. 2016; 185:107-18

52. Mermel CH, McLemore ML, Liu F, Pereira S, Woloszynek J, Lowell CA, Link DC. Src family kinases are important negative regulators of G-CSF-dependent granulopoiesis. Blood. 2006; 108:2562-8.

53. Sampson M, Zhu QS, Corey SJ. Src kinases in G-CSF receptor signaling. Front Biosci. 2007; 12:1463-74.

54. Borneo J, Munugalavadla V, Sims EC, Vemula S, Orschell CM, Yoder M, Kapur R. Src family kinase-mediated negative regulation of hematopoietic stem cell mobilization involves both intrinsic and microenvironmental factors. Exp Hematol. 2007; 35:1026-37.

55. Palacios EH, Weiss A. Function of the Src-family kinases, Lck and Fyn, in T-cell development and activation. Oncogene. 2004; 23:7990-8000.

56. Brownlie RJ, Zamoyska R. T cell receptor signalling networks: branched, diversified and bounded. Nat Rev Immunol. 2013; 13:257-69.

57. Huang Y, Clarke F, Karimi M, Roy NH, Williamson EK, Okumura M, Mochizuki K, Chen EJ, Park TJ, Debes GF, Zhang Y, Curran T, Kambayashi T, et al. CRK proteins selectively regulate $\mathrm{T}$ cell migration into inflamed tissues. $\mathrm{J}$ Clin Invest. 2015; 125:1019-32.

58. Oth T, Schnijderberg MC, Senden-Gijsbers BL, Germeraad WT, Bos GM, Vanderlocht J. Monitoring the initiation and kinetics of human dendritic cell-induced polarization of autologous naive CD4 ${ }^{+} \mathrm{T}$ cells. PLoS One. 2014; 9:e103725. 